\title{
Education on Mercury Exposure from Fish and its Product in Elementary Students in Kenjeran Beach Area, Surabaya: A Study Protocol
}

\author{
Trias Mahmudiono $^{1 *(\mathbb{D})}$, Eurika Zebadia ${ }^{1(\mathbb{D})}$, Nur Sahila $^{2}$, Diah Indriani ${ }^{3}$, Stefania Widya Setyaningtyas ${ }^{1(\mathbb{D})}$ \\ ${ }^{1}$ Department of Nutrition, Faculty of Public Health, Universitas Airlangga, Surabaya, Indonesia; ${ }^{2}$ Department of Health Policy \\ and Administration, Faculty of Public Health, Universitas Airlangga, Surabaya, Indonesia; ${ }^{3}$ Department of Epidemiology, \\ Biostatistics, and Health Promotion, Public Health Faculty, Universitas Airlangga, Surabaya, Indonesia
}

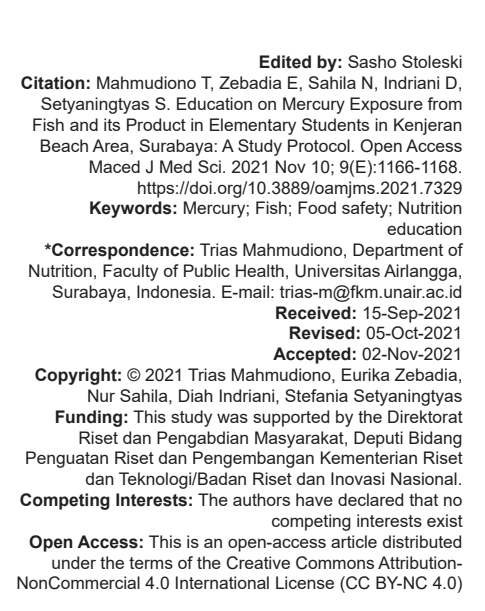

\section{Abstract}

BACKGROUND: Fish are one of the high protein food sources that could be found easily in Indonesia. Recent trends in industrialization and human activity (e.g., agriculture) that started the degradation of environmental quality such as mercury contamination in fish.

AIM: We aimed to investigate mercury contamination in fish because the incident occurs more frequently and could affect the health condition both in the long- and short-term. This study aimed to increase the student's knowledge on the danger of mercury contamination in fish and its products.

METHODS: A quasi-experimental study will be conducted at a public school in Kenjeran District, Surabaya The framework of the Health Behavior Model theory is used to educate the students on the danger of mercury contamination in fish and its products.

RESULTS: This study targets elementary school children with a total of 135 students.

CONCLUSION: This study has been considered by the Health Research Ethics Comitee Universitas Airlangga Faculty of Nursery, with the number: 2359-X-KEPK. The Universal Trial Number for thus study is U1111-12693728 and registered at the Thai Clinical Trials Registry (TCTR) and has been approved with indentification number TCTR20210913003.

\section{Introduction}

Fish are one of the high protein food sources that could be found easily in Indonesia. However, recent trends in industrialization and human activity (e.g., agriculture) that started the degradation of environmental quality followed by ecological imbalance cause a public health concern especially on fish safety that is consumed in areas where the mining and industry activity happens [1]. The food safety problem has become a concern because the incident occurs more frequently and could affect the health condition both in the long- and short-term. This puts a significant health burden on the population. One of the problems is the contamination of heavy metals among fish (freshwater and seawater fish). Heavy metal contamination could cause health disadvantages through many paths such as bioaccumulation and biomagnification in the food chain (consuming contaminated fish), consuming contaminated water, and usage of surface water as daily use to wash and bath [2]. Consuming food or seafood that came from the contaminated sea is the main pathway of heavy metals exposure among humans [3].

Heavy metal contamination in humans had been studied about several health consequences. Mercury contamination is indicated as the agent that causes several harms such as immunology, neurology, reproduction, motoric, nephrology, and cardiac disturbance. Several genetic disorders such as Alzheimer's, Parkinson's, autism, lupus, and amyotrophic lateral sclerosis also were mediated by heavy metal exposure [4]. Effects of methylmercury on 10 years old children that were studied by Gustin et al. [5] were found to be significant with bad behavior from neurotoxicity development.

This study is conducted on schools that are located in the Kenjeran Beach area because they have a higher risk of exposure. Therefore, nutrition education should be given to increase the knowledge and understanding of mercury contaminants in fish and the products. This study is intended to increase the knowledge of elementary students about mercury contamination in fish and the products. 


\section{Study objective}

The study aims to determine the effectiveness of 3 weeks (three meetings) online-based nutrition education related to the mercury contamination in fish and its product using Health Belief Model as the theory framework.

The primary objective is to determine the effectiveness of 3 weeks (three meetings) online-based nutrition education related to the mercury contamination in fish and its product.

\section{Secondary Objective}

1. Determine elementary school students' nutrition knowledge related to the mercury contamination in fish and its product through a questionnaire

2. Determine the elementary school student's perception of their susceptibility to mercury contamination in fish and its product through a questionnaire

3. Determine the elementary school student's perception of the severity of consuming fish or its products that contaminated with mercury through a questionnaire

4. Determine the elementary school student's perception of the benefits and barriers in consuming mercury-contaminated fish or fish products through a questionnaire

5. Determine the elementary student's selfefficacy to consume mercury-free or lowmercury fish from sellers near Kenjeran Beach Area.

\section{Methods}

A quasi-experimental study will be conducted at State Elementary School of Sukolilo 250 located in Kenjeran District, Surabaya. This school is chosen because this school is located near Kenjeran Beach Area. The sample size of this study is counted by simple random sampling with $\alpha=5 \%$. Based on the formula, the sample size that is needed in this study is 123 students and rounded to 130 students.

\section{Setting}

Health Behavior Model (HBM) theory on the danger of mercury contamination in fish and its products will be done to the intervention group meanwhile the control group will get education on salt, sugar, and fat reduction. Pre-test and post-test will be done to both groups to know the different exposure between both groups. The question in the questionnaire will be based on the framework theory of the HBM that can be seen in Table 1. These questions will be answered in five categories, namely, strongly agree, agree, neutral, disagree, and strongly disagree. The education will be given to the students using videos that could be accessed from YouTube. The students will also be given modules consisting of the educational plan and hands-on activity every week for 3 weeks consecutively.

Table 1: Questions based on the framework of HBM theory

\begin{tabular}{|c|c|}
\hline Indicators & Question \\
\hline $\begin{array}{l}\text { Perceived } \\
\text { susceptibility }\end{array}$ & $\begin{array}{l}\text { 1. People who consumed fish and its products have a higher } \\
\text { chance to contaminated with mercury } \\
\text { 2. I have a higher risk of consuming mercury-contaminated fish } \\
\text { because I live near Kenjeran beach } \\
\text { 3. Mercury will only contaminate the sea but will not contaminate } \\
\text { fish } \\
\text { 4. If the sea is contaminated with mercury, it will contaminate } \\
\text { waters that I consume }\end{array}$ \\
\hline Perceived severity & $\begin{array}{l}\text { 1. Consuming mercury-contaminated fish will disturb a child's } \\
\text { brain development } \\
\text { 2. Consuming mercury-contaminated fish will not disturb the } \\
\text { sensory system } \\
\text { 3. Consuming mercury-contaminated fish products will not disturb } \\
\text { the nervous system } \\
\text { 4. Consuming mercury-contaminated fish and its products will not } \\
\text { disturb my long-term health condition }\end{array}$ \\
\hline $\begin{array}{l}\text { Perceived benefits } \\
\text { and barriers }\end{array}$ & $\begin{array}{l}\text { 1. Consuming fish from the Kenjeran beach area is cheap } \\
\text { 2. Freshwater fish is hard to find in the Kenjeran Beach area } \\
\text { 3. My parents could cook me a mercury-free fish dish } \\
\text { 4. My parents could differentiate between fish and its product that } \\
\text { contaminated with mercury and not }\end{array}$ \\
\hline $\begin{array}{l}\text { Taking health-related } \\
\text { action }\end{array}$ & $\begin{array}{l}\text { 1. I will consume fish and its products } \\
\text { 2. I will consume more freshwater fish compared with sea fish } \\
\text { 3. If I bought fish, I will choose fresh fish } \\
\text { 4. If I bought fish, I will choose fish that does not have a sour odor }\end{array}$ \\
\hline
\end{tabular}

\section{Variables used in this study}

The dependent variable of this study is nutrition education on the danger of mercury contamination in fish and its products using HBM theory. The independent variable in this study is the student's level of knowledge of the danger of mercury contamination in fish and its products using HBM theory.

\section{Analysis method}

Data will be collected through a pre-post-test questionnaire and given to all participants (both for intervention and control group) online. All available data will be analyzed descriptively as frequencies and percentages for nominal data. Inferential analysis that is used in this study is the at-paired test to know the difference between and after the intervention and the t-independent test to know the difference between the intervention and control group. All the statistical analyses before will be performed using IBM SPSS 25 software.

\section{Ethical consideration}

The study will be performed by ethical principles that have their origin in the World Health OrganizationCouncil for International Organizations of Medical Sciences (WHO-CIOMS). This study has already been 
considered by the Health Research Ethics Committee, Universitas Airlangga, Faculty of Nursery, with the number: 2359-X-KEPK. The Universal Trial Number for this study is U1111-1269-3728. This study has been registered at the Thai Clinical Trials Registry (TCTR) and has been approved with identification number TCTR20210913003.

\section{Discussion}

In this study, we suggested education on mercury exposure from fish and its product. This study may lead to recommendations for potential effective strategies that can be used. This study set is in the coastal area of Kenjeran, Surabaya, Indonesia. Kenjeran coastal waters were chosen because it is the center of waters and fisheries in the city. With industrial development in Surabaya growing rapidly, the increase in the number of these industries will always be accompanied by many environmental problems caused by these industrial activities [6].

Mercury can enter the body of aquatic organisms in three ways: Through the food chain, the diffusion surface of the skin, and through the gills. Of the three ways, the most likely way for mercury to enter the body is through the food chain, because almost $90 \%$ of toxic materials or heavy metals mercury enters the body [7]. (The fish are widely used to evaluate the health of aquatic ecosystems because pollutants build up in the food chain, and handle adverse effects and death in the aquatic systems. Therefore, it is important to educate people about mercury exposure from fish and its products.

Education on mercury has been implemented in Central Lombok Regency as a result of illegal gold mining. The previous research showed that social media are needed to provide information on the dangers of mercury with educative persuasion, in providing understanding, with simple and interesting material presented [8]. One of the media that are representative and fulfills the requirements is an educational video based on 2D animation. In that study, education was carried out through 2D animated videos to introduce the dangers of mercury to the people of Central Lombok Regency as a result of illegal gold mining.

This study proposal aimed to educate students on elementary schools in Kenjeran Beach, Surabaya. Elementary educational institutions are an important period in individuals' educational process and elementary educational institutions aim to have students acquire basic knowledge. During elementary education, children encounter many problems that they are supposed to cope with within a social sense [9]. As a consequence, it is important to be able to educate elementary students. Hopefully, this research can provide information and education to elementary students related to mercury exposure from fish and its product.

\section{Conclusion}

This study has been considered by the Health Research Ethics Comitee Universitas Airlangga, Faculty of Nursery, with the number: 2359-X-KEPK. The Universal Trial Number for thus study is U1111-12693728 and registered at the Thai Clinical Trials Registry (TCTR) and has been approved with indentification number TCTR20210913003.

\section{References}

1. Food and Agriculture Organization. IWMI. Water Pollution from Agriculture: A Global Review Executive Summary. Food and Agriculture Organization of the United Nations and the International Water Management Institute; 2017. Available from: http://www. fao.org/3/a-i7754e.pdf. [Last accessed on 10 Sep 2021]

2. Yousif R, Choudary MI, Ahmed S, Ahmed Q. Bioaccumulation of heavy metals in fish and other aquatic organisms from Karachi Coast, Pakistan. Nusant Biosci. 2021;13(1):73-84.

3. Tchounwou PB, Yedjou CG, Patlolla AK, Sutton DJ. Molecular, clinical and environmental toxicicology Volume 3: Environmental Toxicology. Mol Clin Environ Toxicol. 2012;101:133-64.

4. Zahir F, Rizwi SJ, Haq SK, Khan R. Low dose mercury toxicity and human health. Environ Toxicol Pharmacol. 2005;20(2):351-60.

5. Gustin K, Tofail F, Mehrin F, Levi M, Vahter M, Kippler M. Methylmercury exposure and cognitive abilities and behavior at 10years of age. Environ Int. 2017;102:97-105. http://doi. org/10.1016/j.envint.2017.02.004 PMid:28216013

6. Fithriyah A, Rusmiati, Narwati. Perbedaan Kadar Logam Berat Merkuri (Hg) Pada Ikan Tenggiri (Scomberomorus Commerson) Yang Dijual Di Pantai Kenjeran Surabaya Tahun 2015. Gema Lingkung Kesehat. 2016;14(1):16-9.

7. Palar H. Pencemaran dan Toksikologi Logam Berat. Jakarta: Rineka Cipta; 2008.

8. Yusa IM, Rukmi L. Video Edukasi Animasi 2 Dimensi Mengenai Bahaya Merkuri Terhadap Masyarakat Kabupaten Lombok Tengah. Andharupa. 2017;3(2):176-95.

9. Dean J. Improving Children's Learning: Effective Teaching in the Primary School. Vol. 190. Milton Park, Abingdon-on-Thames: Routledge; 2000 